\title{
The New Cycle of Internationalisation of a Southern European Telecommunications Company at the Early 21st Century: Telefónica
}

\author{
Ángel Calvo ${ }^{1}$ \\ ${ }^{1}$ University of Barcelona, Spain \\ Correspondence: Ángel Calvo, University of Barcelona, Spain.
}

Received: April 27, 2021; Accepted: May 13, 2021; Published: May 17, 2021

\begin{abstract}
The telecommunications sector entered the new millennium with a new paradigm, defined in four terms: mobile and global in nature, private, competitive and with interests in different sectors. Within this framework, the research presented here addresses the new cycle in Telefónica's internationalisation and the intricate investment process in Spanish telecommunications. The text is structured in four main sections, comprising an overview of Telefónica in the world market, Telefónica's entry into Central Europe with Český Telecom, the entry into unexplored European markets with $\mathrm{O} 2$ and the penetration of subjectively distant markets - China.
\end{abstract}

Keywords: Telefónica, internationalisation, Spanish telecommunications, mobile telephony

\section{Introduction}

At the dawn of the new millennium, the International Telecommunication Union (ITU), the telecommunications institution par excellence, spoke of reinvention of the sector and a new era ushered in by the gale of creative destruction, a dawn in which scarcity was to be replaced by abundant and ubiquitous service. The industry appeared once again at a crossroads where technological change - mobile telephony and the Internet, an essential component of business and society - intersected with new market realities. Four words summed up the new telecommunications market paradigm of the day: Private, competitive, mobile and global in nature, with interests spanning different sectors (Note 1).

But the buoyant situation of 2000 - almost a trillion dollars in terms of service revenues and almost $\$ 50$ billion in profits generated by ten US operators - took a radical turn. Stock prices plummeted, new infrastructure initiatives - satellites (Iridium) and fibre optic cable (Global Crossing) - ended in bankruptcy. The Internet, the talisman of the 1990s and the ultimate expression of dot.com technologies, became a dirty word in the new century as dot.bomb.

This requires some explanation. After a long period of industry growth at rates of five to seven percent per year, the mid-1990s saw a growth spiral to a peak of 28 percent in 2000. It was a time of sustained high investment, mainly in building new networks and expanding old ones (in 2000, incumbent telecom operators invested more than $\$ 200$ billion, almost twice as much as a decade earlier). Investment was also directed towards the acquisition of shares in telecommunications companies (privatisations amounted to more than $\$ 100$ million in the last years of the 20th century) and licences to provide services (about the same amount in the first years of the 21st century). In the face of limited consumer capacity, the price reductions brought about by competition and the squeeze on profit margins broke investors' confidence. Venture capital was reluctant to build new networks in the already well-supplied countries of the developed world and speculative investments took refuge in the poorly serviced emerging nations with strong growth prospects (Note 2). Privatisation revenues in the infrastructure sector in Eastern Europe reached \$7.2 trillion in 2006, close to the sum of East Asia and the Pacific (\$5.8 trillion) and Latin America ( $\$ 2.7$ trillion). By country, 86\% of privatisations in East Asia and the Pacific in 2006 took place in the People's Republic of China, while Mexico accounted for $51 \%$ of privatisations in Latin America (Note 3).

Against the backdrop of the global market, this research addresses the new cycle in Telefónica's internationalisation and the intricate investment process in Spanish telecommunications. It derives from primary sources and reports from international institutions, among them the International Telecommunication Union and OCDE. The text is structured in four main sections, comprising an overview of Telefónica in the global market, Telefónica's entry into Central Europe with Český Telecom, the entry into unexplored European markets with O2 and the penetration of subjectively distant markets - China. 


\section{Telefónica in the Global Market}

Telefónica was the monopoly of the telecommunications in Spain, a condition kept for 74 years. It has been created by the gigantic International Telephone and Telegraph Co. (IT\&T) in 1924, when the country was under the dictatorship of the general Primo de Rivera. With the name of Compañía Telefónica Nacional de España (CTNE), it served almost the entire territory. In conjunction with its monopoly on telephone service, the CTNE had close ties with Standard Eléctrica, a supplier of equipment and materials founded by IT\&T. CTNE overcame successive attempts at nationalisation, in particular during the Second Republic (1931-1936), and was rescued by Spanish capital under Franco's dictatorial regime. In the long period that began in 1946, it maintained its monopoly under a new contract with the State and even reinforced it with the recovery of some provincial networks that persisted outside its control. Vertical integration with Standard Eléctrica was first weakened in the 1960s through the formation of the so-called second suppliers and was definitively broken when Spain joined the European Economic Community in 1986. Then, in order to gain the advantages it obtained from its integration into the industry with a critical size for negotiating with suppliers, it began a first phase of internationalisation, in particular with a major expansion across Latin America during the mandate of Luis Solana Madariaga, who faced stiff opposition in government and parliament.

Spain officially opened its telecommunications market to competition on 1 December 1998, eleven months behind the majority bloc of EU countries (Note 4). The reduction in prices and increase in traffic following the liberalisation of telecommunications led to an upward loss of market share for the former monopoly, especially in long-distance and international calls, as well as calls to mobile phones (Note 5). Following its full privatisation, Telefónica set out to move towards a less capital intensive, more agile and efficient business model, with the ability to optimise capital expenditure and the willingness to reallocate a good half of its spending on new and broadband service.

In the past, Telefónica has had a long history of forging international alliances, a strategy that has been further developed in the following years (Note 6). In May 2000, together with Bertelsmann and Terra, it entered into a strategic agreement, which was replaced after almost three years by a strategic alliance framework agreement. In addition, the three companies and Lycos reached a preferential agreement in order to further explore opportunities for the mutual provision of communication services, developments and content in the on-line market. The new agreement between Telefónica and Terra was twofold. On the one hand, it responded to the changes experienced by the Internet business, especially the development of broadband; on the other hand, it responded to the need to adapt the products and services offered by Terra Lycos under the 2000 agreement to the new realities and the specific needs of the Telefónica Group. The aim was to add the capacity of this Group, as a connectivity and access provider, to those of the Terra Lycos Group as a fixed telephony Internet portal in the residential, SOHO and, when agreed, SME markets, taking advantage of synergies and creating value for both Groups (Note 7).

This brings us into another realm of new expectations, created by technological change and, more specifically, by the Internet.

Shortly before the end of the 20th century, Telefónica formed Terra Networks, S.A. (Note 8), which followed a strategic model with a separation between the telecommunications business and the Internet Service Provider (ISP) business. But the development of broadband technology applied to Internet access erased the traditional separation between the two businesses and imposed changes from the supply and demand side. This new integrated model of telephony and Internet precipitated the irreversible crisis of the traditional pattern and the emergence of a new offer that only seamless integrated management between network functions and service provision could capture. This integration of connectivity, access and service layers required Internet access providers to become communications operators in order to compete in the market. Thus, they had only two alternatives: either to invest in network infrastructure (which may compromise their viability given the time to maturity of the investment and the high capital required to undertake it) or to fully integrate with network operators already possessing infrastructure and technical and human capacity.

On the demand side, users, no longer satisfied with Internet access alone, were looking for integrated offers and therefore opted for operators capable of offering all the services demanded by the market, in particular voice, image and Internet access, among others. Competing in a market that was growing in size and changing in terms of offerings required increasingly higher capacities, scale and resources in the context of the technological evolution of services - rapidly increasing connection speeds, technical capacity to provide quality audiovisual content, interoperability between the different elements of the offer (mail, messages, voicemail, content consumption, etc.) -. Hence the propensity of competing groups to make broadband the core of their strategy by integrating telephony and Internet businesses (Note 9). 
Offering integrated solutions to the user was the path Telefónica intended to take to successfully face the new challenges, which made the merger with an Internet company a strategic imperative. In this regard, the integration of the businesses resulting from the merger with Terra had many advantages, starting with an increase in customers and market share, and continuing with the improved utilisation of existing customer bases. The integration would minimise costs and optimise investments through integrated management of networks and platforms, rationalisation of investments, rationalisation of corporate structures with elimination of duplication and, therefore, improved management and increased efficiency and ease of capturing content and service synergies. Integration would in turn allow exploiting growth opportunities in new markets through a more attractive and competitive fixed telecommunications offer using broadband Internet access. Finally, it would make it possible to develop a unique strategy in the field of e-commerce and general portals for access to information and advertising (Note 10).

In those early years of the new millennium, full of change and turbulence, investors began to talk about mature markets, which, at least in part, were already frequented by Telefónica. The Group spread its investment activity in European and, especially, Latin American markets through shareholdings and acquisitions. This practice included the stake in Portugal Telecom (29 April 2004); the acquisition of BellSouth's total stakes in its Latin American operators and the voluntary takeover bids for the shares of four Brazilian subsidiaries (Tele Sudeste Celular Participaçoes, S.A. (TSD), Tele Leste Celular Participaçoes, S.A. (TBE), Celular CRT Participaçoes, S.A. (CRT) and Tele Centro Oeste Celular Participaçoes, S.A. (TCO). These bids raised Brasilcel's stake to $90.9 \%$ in TSD, $50.6 \%$ in TBE and $67 \%$ in CRT. Telesp Celular's stake in TCO reached $50.6 \%$. Together, the total amount of these takeover bids was around 168 million euros for Brasilcel and 249 million euros for TCP. In accordance with the Company's usual practice, this operation was financed with liquidity and available credit lines (Note 11).

Some key facts should be recalled at this point. In April 1997, Portugal Telecom and Telefónica sealed a partnership agreement in order to explore the possibility, among other things, of jointly evaluating international expansion and development opportunities, with a particular focus on Latin America. This was a strategic decision in response to investor demand for consolidation in Brazil with the aim of taking the consolidation initiative and creating the largest wireless operator in South America. In January 2001, the two companies together with their respective subsidiaries, PT Moveis SGPS S.A. and Telefónica Móviles S.A., created in equal parts a leading wireless and mobile operator in Brazil, domiciled in the Netherlands under the name Brasilcel N.V. In October 2002, by a subscription agreement, both companies contributed their Brazilian wireless and mobile assets to Brasilcel, while by a shareholders' agreement they regulated their respective interests in Brasilcel, as well as the governance and development of Brasilcel and its subsidiaries. The joint venture began operating in Brazil under the Vivo brand in April 2003 and, subsequently, Brasilcel concentrated all its interests in a single holding company under the name Vivo Participações S.A. Vivo became the leading provider of mobile telecommunications services in Brazil (Note 12).

Consider now some of the operations mentioned above, in particular Centro Oeste Celular, well analysed by Telefónica (Note 13).

Mergers, takeover bids and divestitures were also significant transactions in 2005-2006. These included the merger by absorption of Terra Networks by Telefónica (23 February 2005), the IPO of Endemol N.V. and its listing on Euronext Amsterdam (10 November 2005), the sale of TPI (4 July 2006), the British telephone directory company, and of Yell Group plc ("YELL"). The merger through absorption of Telefónica Móviles by Telefónica implied the extinction, through the dissolution without liquidation of the former and the en bloc transfer of all assets to the latter (21 June 2006) (Note 14).

Consider the acquisition of BellSouth's stakes in its Latin American operators in Argentina, Chile, Peru, Venezuela, Colombia, Ecuador, Uruguay, Guatemala, Nicaragua and Panama (Note 15).

In March 2004, BellSouth and Telefónica Móviles had reached a definitive agreement, whereby BellSouth sold its stake in ten Latin American operators to Telefónica Móviles. The agreement provided for a purchase price based on the total value of $\$ 5.85$ billion. The transaction was to be closed in stages by the end of 2004 with the transfer of BellSouth's stake in the operations in seven Latin American countries (Argentina, Chile, Colombia, Nicaragua, Peru, Uruguay and Venezuela), subject to all necessary government approvals (Note 16).

Telefónica considered the transaction a "natural" strategic move for Telefónica Móviles, which consolidated its leadership in Latin America through local scale expansion in the main countries (Argentina, Chile and Peru). This objective was achieved by expanding presence in a high-growth region, improving market fundamentals via a reduction in the number of companies, integration with existing operations in the region with substantial benefits from economies of scale and synergies, strengthening Telefónica Móviles' diversified profile, increasing EPS and PFC from the outset, and managing execution risk and proven management track record (Note 17). 
Table 1. Telefónica Móviles' Latin American portfolio, 2003

\begin{tabular}{|c|c|c|c|c|c|}
\hline & $\begin{array}{l}\text { Inhabitants } \\
\text { (millions) }\end{array}$ & $\begin{array}{l}\text { Penetration } \\
(\%) \text { of mobile phones }\end{array}$ & $\begin{array}{l}\text { Subscribers } \\
\text { (thousands) }\end{array}$ & Market share & $\begin{array}{r}\text { Place in the } \\
\text { market }\end{array}$ \\
\hline Chile & 15.4 & 49 & 3,571 & 48 & 1 \\
\hline Argentina & 36.9 & 21 & 3,311 & 42 & 1 \\
\hline Peru & 27.3 & 11 & 2,149 & 74 & 1 \\
\hline Uruguay & 2.1 & 23 & 146 & 30 & 2 \\
\hline Venezuela & 24 & 31 & 3,307 & 45 & 1 \\
\hline Colombia & 40.3 & 15 & 1,915 & 32 & 2 \\
\hline Ecuador & 13.2 & 18 & 816 & 35 & 2 \\
\hline Panama & 2.8 & 27 & 420 & 55 & 1 \\
\hline Guatemala & 11.1 & 16 & 409 & 22 & 3 \\
\hline El Salvador & 6.6 & 13 & 248 & 25 & 2 \\
\hline Nicaragua & 2.9 & 11 & 229 & 69 & 1 \\
\hline Brazil & 130.1 & 35 & 20,656 & 56 & 1 \\
\hline Mexico & 103.9 & 30 & 3,454 & 11 & 2 \\
\hline Puerto Rico & 3.9 & 34 & 175 & 12 & 4 \\
\hline
\end{tabular}

The acquisition of the entire capital of all ten BellSouth cellular operators in Latin America mobilised $\$ 5.85$ billion through cash generation financing $-\$ 4.2$ billion- and debt from Telefónica Móviles. The transaction boosted Telefónica Móviles to the second largest mobile multinational in the world, with close to 72 million customers under management in the third quarter of 2004 and the largest operator in Latin America, with more than 50.6 million customers under management. In addition, it was the only mobile company with a presence in the region's main markets, which together had more than 421 million inhabitants. All these figures put the company in a good position to take advantage of the strong potential boom in the Latin American market.

The acquisition capped key acquisitions in Latin America for Spain's largest company, which could always continue with organic growth and the occasional small purchase if opportunities arose. Including the BellSouth purchase, Telefónica had invested almost 43 billion euros in fixed and mobile lines in the previous decade (Note 18).

\section{Telefónica's European Cycle: At the Heart of Europe}

At the turn of the millennium, Telefónica's strategic objective was to obtain licences to operate mobile services in Europe using UMTS technology. The strategy in the third generation of mobile telephony, driven by Telefónica Intercontinental as a special purpose vehicle, was pan-European in nature, albeit subject to a threefold selective criterion. Firstly, it gave priority to the markets of the four major countries - the UK, Germany, France and Italy and one of the most advanced, namely Switzerland. Secondly, it focused on the profitability of the investment, while at the same time reducing risks through alliances with technological and financial partners that would limit its financial exposure without losing control of operations. In this search for allies, the choice of local partners also became very important. However, the entry strategy took different forms depending on the countries it planned to enter (Note 19).

Telefónica benefited from the status of a private monopoly with a significant public shareholding, backed by the government as an economic development and intervention player and also as an element of the political game as the company's chief executive. This gave Telefónica enormous financial power and a position of lower indebtedness than other major European operators. When the auctions put pressure on the technology to make the market potential profitable in the short term without adequate technological deployment, the most technologically powerful companies and consortia failed. In effect, their technological capacity was devalued, but Telefónica's profitability was not so affected.

The Spanish predominant operator undoubtedly had its sights set on the global market. On a less sectoral and more geographical level, the inclusion of One.Tel in the Telefónica consortium was related to broader joint plans. Indeed, both negotiated a possible participation of the Spanish company in the capital of the Australian one. The interruption of the talks due to the change of Telefónica's chairmanship prevented the possibility of Telefónica's presence as a network operator in distant markets (Note 20).

Eastern Europe as a whole, in transition to a market economy after the collapse of the Soviet bloc, had the characteristics of emerging countries. Early in the millennium, the newly appointed centre-left Czech cabinet 
decided to follow the path of so many other countries and privatise the public telephone monopoly through a partial sale of $51 \%$ of Český Telecom (CTe) (Note 21). In 2002, it launched a $\$ 1.8$ billion (1.82 billion euros) sale to a consortium formed by Deutsche Bank and the Danish operator TDC. The mixed nature of the consortium was explained by the presence of a financial institution and the Danish leader TDC, $41 \%$ owned by the US operator SBC, which, without providing financing, would take over management control. The competing consortium that was left in the lurch, comprising two investors - the US Spectrum Equity Partners and the UK's CVC Capital Partners - and the Swiss operator Swisscom, had the same mixed composition (Note 22).

The government of the second of the ten new EU member states intended to use the proceeds from the sale of Český Telecom for the construction and modernisation of roads and railways and to avoid a conflict between its role as shareholder and market regulator (Note 23).

After first relaunching the sale by urging the bidders to make an additional effort of at least $10 \%$, the Executive finally suspended the sale because of the companies' refusal of a controlling minority transaction (Note 24).

Three years on, the government went back to the drawing board, this time to offer CTe to strategic investors before turning to the capital markets, over the objections of the finance minister and to the disappointment of local investor PPF. The Czech government, mired in a protracted crisis, unanimously approved on 6 April the sale of the stateowned monopoly Český Telecom, together with its subsidiary Eurotel.

The preliminary bidding for the Czech operator was open to five entities, three of which were operators - Belgacom, Telefónica and Swisscom - and two consortia, the first strictly financial - the US Blackstone Group, CVC Capital Partners and Providence Equity - and the second mixed - the Czech holding company PPF, Tiscali, the Slovak financial company J\&T and the data telecommunications company InWay. The government made access to CTe's data room documentation conditional on the latter two bidders integrating partners with experience in telecoms management. InWay (a subsidiary of PPF) apparently did not meet the conditions. Financial bidders could turn to companies such as France Telecom or Vodafone, which had shown interest but did not actually participate in a preliminary bid (Note 25).

The surprise came when the financial group of the Czech holding company PPF decided to withdraw from the tender with its consortium - J\&T, Inway and Tiscali - as PPF had bid the highest bid for the state-owned company. It claimed that it did not have access to the operator's due diligence, an accusation rejected by CTe. The latter's manager, Gabriel Berdar, pointed out that "PPF had normal access to the data room and Tiscali was told it would have special access", adding that PPF and Tiscali representatives did not even start negotiating (Note 26). In reality, the surprise proved to be relative for several sources close to the bid, who were convinced that PPF's interest in Český Telecom was purely speculative and lay in undermining the tender in order to obtain a lucrative deal with the incoming government. PPF could have joined the bid only to generate money from the speculative purchase of CTE shares, a good number of which it had bought prior to the bid (Note 27).

To return to one of the players, at that time, Telefónica based its strategy on two priorities, namely to maintain its leadership in the fixed telecommunications market to ensure revenue generation and to become the communications provider of choice in Spain as a guarantee for the future (Note 28). At the end of 2006, the Telefónica Group's tangible and intangible investments totaled 5,067 million euros, distributed between Telefónica de España (906 and 143), Telefónica Latinoamérica (652 and 85), Telefónica Móviles (1,072 and 229), O2 Group (1,255 and 277), Český Group (108 and 34), Telefónica Contenidos (36 and 1), Atento (17 and 2) and Resto and eliminations (239 and 11) (Note 29).

Telefónica entered the privatisation of Český Telecom A.S. in competition with operators and financial groups. At the end of March 2005, it submitted a binding offer for the acquisition of $51.1 \%$ of the capital of the aforementioned company with a total bid of EUR 2,745.87 million. A few days later, the Czech government officially proclaimed Telefónica the winner. After obtaining authorisation from the European Commission, Telefónica and the National Property Fund closed the sale and purchase on 16 June 2005 (Note 30).

The takeover of a $51.1 \%$ controlling stake in the monopoly Český Telecom AS for USD 3.6 billion was the second largest sale of a state asset in the country's history, narrowly beating Swisscom and Belgacom (Note 31). With the takeover of the Czech company, leader in that country, the Telefónica Group, the third largest in the world by market value, gained access to a market characterised by high mobile penetration and continued pressure in the fixed and mobile technology segment (Note 32). At the same time, it strengthened its position as a global telecommunications operator - it surpassed 130 million customers worldwide (Note 33) - and its position as a leading integrated operator by broadening the geography of its operations from its base in Spain to Europe, Africa and Latin America. It also expanded the scope of its operations to include electronic telecommunications (fixed 
and mobile telephony, business services, data transmission, Internet access, directory marketing and directories, CRM, services, broadband and submarine cable infrastructures) (Note 34).

Days after closing the sale and purchase of Český Telecom, Telefónica submitted to the Czech Securities Commission for approval a mandatory takeover bid for $48.9 \%$ of the shares in a transaction which, upon closing, raised Telefónica's stake from 51.1\% to $69.4 \%$ for an approximate outlay of EUR 917 million (Note 35).

Take a moment to consider the significance of Telefónica's plans with the takeover of Český and the possible start of a new phase in the company's international expansion plans (Note 36).

Financial circles were divided on the deal. On the benevolent side, Lehman Brothers had expected a bemused reaction to the acquisition strategy of Telefonica, which had previously focused on Latin American expansion and had recently acquired BellSouth. However, he admitted an increased interest by Telefónica over the past year in regional activities in Europe, particularly in the UK and Germany. Český Telecom presented a company profile with a solid financial base and increasingly low costs. Moreover, Český was also the dominant operator in a new EU member country which was expected to play an increasing role in the economic growth of Central and Eastern Europe, although this process could take several years (Note 37). On the critical camp, Crédit Suisse, Goldman Sachs and the Wall Street Journal, criticised the Český Telecom deal with harsh words (Note 38).

It does not appear that the financial circles were fully aware of Telefónica's intentions, but it is clear that they knew that this operator - the third largest in the world and the second largest multinational - was not limiting its expansion to Latin America, a region that was beginning to show signs of a certain maturity. Looking at the possible movements of some companies in Eastern Europe, including Vodafone, they did not rule out Telefónica playing its trump card. In fact, Telefónica soon reported that it had participated in the due diligence process of Türk Telekom and that, prior to finalising the terms of a possible proposal, it considered that the appropriate conditions were not in place to bid for the privatisation of the Turkish company (Note 39).

One might ask why Český Telecom did and Türk Telekom did not at such close dates. By population and per capita income (70 million inhabitants with approximately \$8,500 GDP per capita) Turkey was the largest telecommunications market in Central and Eastern Europe, the Middle East and Africa. The Turkish fixed-line market was the largest in the region and had achieved growth in broadband and mobile penetration. Turk Telekom was the public telecommunications monopoly in Turkey, established in 1995 when the telecommunications business was separated from the Post, Telegraph and Telephone Directorate General (PTT) (Note 40). In 1996, the constitutional court made a decision to allow the sale of Turk Telekom.

On the Turkish side, the government, under the aegis of the International Monetary Fund, promoted a transparent process for the sale of state assets, in which TT figured prominently. Obliged by an IMF loan agreement to meet a surplus target of $6.5 \%$ of GDP, Turkey, one of the leading exponents of the Washington consensus (Eichengreen, 2002, p. 1), had to put a high sale price on its assets in order to meet the surplus. The IMF not only set the guidelines but meddled in the process by pushing to replace Turk Telekom managers opposed to, or unenthusiastic about, privatisation with others sympathetic to its policies (Note 41).

It is now time to delve into the well of oblivion by explaining an operation that has left little trace, although, together with others in previous years, it helped to reinforce the economy of experience (Note 42).

Even before Turkey, shortly after the fall of the Berlin Wall, Telefónica saw the new possibilities that were opening up in the countries of the Soviet bloc in the midst of transformation. It explored entry into Bulgaria, from where it withdrew from the privatisation of Bulgarian Telecommunications Company (BTC) after due diligence. In 2000, the Bulgarian government refused to sell BTC to a consortium of Greece's OTE and the Netherlands' KPN, which offered $\$ 610$ million for a 51\% stake, including a mobile licence. After a two-year stalemate, Bulgaria sold BTC to Viva in a deal that represented the largest privatisation in Eastern Europe (Note 43). Telefónica entered Bulgaria under a different modality, common to a group of European countries. In 2009, it opened new offices in a further 14 European countries - France, Belgium, Greece, Italy, the Netherlands, Portugal, Sweden, Denmark, Estonia, Poland, Hungary, Switzerland, Austria and Romania. The expansion was aimed at enhancing integrated telecommunications services for corporate customers (Note 44).

\section{The Entry to the Chinese Market}

Significantly, Telefónica claimed its multinational dimension and presented clear objectives of integration and cultural change, realities based on the evolution of its own businesses in Spain and Latin America as well as on recent operations. At that time, it advocated making results-oriented management a priority objective in all business lines and making the most of the benefits derived from the Group's scale, positioning and leadership. In addition to the acquisition of Cesky Telecom, he added in his analysis the successful integration of the mobile 
operations acquired from BellSouth, the strategic investment of 5\% in China Netcom and the planned addition to the Group of the UK's O2, with a significant presence in the UK, Germany and Ireland (Note 45).

Telefónica de España's entry into China's state-owned telecoms - the climbing of the Chinese wall - through a strategic alliance with China Netcom (CNC) and a \$290 million contribution for a 2.99 per cent stake in this fixedline company, the second largest in the country after China Telecom, gave Telefónica access to a region with great potential and opened up a fertile avenue for collaboration between the two companies (Note 46).

Far from improvisation, the operation required some time to mature, with moments of limited success. In 2005, Telefónica even created an office in Beijing with the aim of sounding out the possibilities in that country, a move prior to direct investment that is very dear to some of the great theories of internationalisation, such as the Stockholm or Nordic school (Note 47).

The plan was to be implemented in phases over a relatively short period of time, so that the initial percentage would be up to $5 \%$ of CNC's capital, with a total investment of 400 million to qualify for the right to appoint a member to the board of directors. In this feature the agreement depended on external factors, such as the relaxation of foreign investment imposed by China's entry into the World Trade Organisation (WTO) in 2001, which allowed a Western group to control up to $49 \%$ of fixed-line operators from 2008 . The difficulty of the gamble was obvious, as were the benefits of Netcom eventually controlling Hong Kong's fixed and mobile communications and becoming an integrated operator by acquiring one of the $3 \mathrm{G}$ mobile licences (Note 48 ).

The strategic cooperation agreement encompassed virtually all activities of the two operators, from joint purchasing to network and customer management, to $R \& D$ of new products and services. More precisely, the possible areas of cooperation between the parties included ten topics: international business area; the existing business of the company and its parent company; the provision of telecommunications companies and services in the southern provinces of the PRC; business call centre; management exchange with Telefónica and company executives every six months during the term of the agreement; cooperation and exchange in many areas; cooperation in the purchase of technology, terminals, infrastructure, distribution or usage rights and other components; technology assistance and knowledge transfer provided by Telefónica in various areas; provision of mobile service and other mutually agreed forms of cooperation (Annex 2) (Note 49).

Telefónica faced risks arising from a number of technological and regulatory factors: markets subject to intense technological renewal that required constant technological innovation; subjection to the terms and conditions imposed by the governments of each country when granting licences to provide services; user animosity towards mobile telephony due to the potential health problems caused by radio electric emissions (Note 50).

To these were added the specific risks of the Telefónica Group, starting with country risk (investments in Latin America) and continuing with those associated with the management of exchange rate or interest rate risk; relations with partners in joint ventures not controlled by Telefónica; the greater solvency risk arising from acquisitions and, therefore, greater financial vulnerability and less strategic flexibility; acquisitions and business integrations and, finally, litigation and other legal proceedings pending before courts and arbitration bodies in the various countries.

If we look at country risks, we find up to seven elements of a political, regulatory, monetary, fiscal and economic policy nature. In detail, they related to possible abrupt changes in policies and/or regulation; devaluation of local currencies or imposition of restrictions on the exchange rate regime or on capital movements; negative equity situation in Group subsidiaries and consequent recapitalisation or start of the dissolution process due to the effects of inflation and/or possible devaluation of local currencies; possible public expropriation of assets; possible imposition of excessive taxes or duties; possible political changes that could affect the economic or business conditions of the market in which it operates; the possibility of economic crises, or situations of political instability or public unrest, which could adversely affect the Group's operations in these countries.

In addition, and from a general perspective, country risk also had an impact on the Group's market value in these countries, revenues, dividends and management payments for these companies. An adverse economic situation in these regions could affect demand, consumption and the exchange rate in these countries (Note 51).

The Turkish financial community received with deep unease the decision of Telefónica, considered the overwhelming favourite to buy Turk Telekom because of its financial, operational and management expertise needed to modernise the fixed line monopoly (Note 52).

The privatisation of TT dated back to the early 1990s and had encountered repeated delays, legal obstacles, adverse political sensitivities, disputes over the terms of reference and outright cancellation of internal sales. Because of this long history of failed privatisation attempts, there was little doubt about the likelihood of a successful outcome. After two failed attempts to sell 20\% of TT in September 2000 and 33.5\% in May 2001, at the end of 2004, the 
Turkish privatisation agency announced the opening of the tender for the privatisation of 55\% of Turkey's fixedline telecommunications monopoly, Turk Telecom (TT), for which a "strategic investor" was sought (Note 53).

After an initial enthusiastic response, the thirteen qualified bidding groups were reduced to eight. Telefónica was joined in dropping out by four others - Belgacom, Malaysian Multi Global Link, South Korean SK Telekom and Turkish MNG/MAPA Company. Three foreign contenders remained in the running, the most enthusiastic ones Telecom Italia, considered one of the front-runners, and Emirates Telecommunications Corp (Etisalat)/Dubai Islamic Bank/(Turkish) Cetel Calik Enerji (recent winner of the Albania Telecom bid) and Saudi Oger Telecom and five local competitors, still looking for partners: Koc Holding (prominent business group which had broken the partnership with the Sabanci group, the country's second largest conglomerate which intended to bid alone; Dogan Companies Group (leading Turkish media group); OYAK (army pension mutual); Turktell Bilisim Servisleri (subsidiary of mobile leader Turkcell), leading a joint venture; finally, Turkish Privatization Investors (Note 54).

But come to the motivations. These had a strong strategic overtone, namely the high opportunity cost of the deal due to competing investment opportunities and concerns expressed about the valuation and management of Turk Telekom's $40 \%$ stake in Avea's mobile operator. To add to the confusion, Telecom Italia, one of the main bidders - owner of a $40 \%$ stake and management control of Avea - announced its withdrawal from Avea if it does not emerge victorious in the bidding for TT. An additional argument for Telefónica's decision is the lack of interest shown by American and European companies, led by Deutsche Telekom, which have been unsuccessfully courted by the Turkish authorities. In fact, already in 2001 the Turkish privatisation agency gave priority to the German company in the roadshow aimed at potential buyers of a minority stake in the telephone monopoly (Note 55).

It is not explicitly stated, but the due diligence process should undoubtedly have revealed an atmosphere of uncertainty to Telefónica's experienced staff, which is also apparent to other observers. No less than 61,000 employees would be affected by the privatisation of the company and the administration could put obstacles in the way of a perceived low price for one of the "jewels in the crown", as it did in the decision to cancel the tender for the Tekel tobacco company. Not to mention resistance from the Turkish establishment to the privatisation of a strategically important asset or pressure from trade unions. Another challenge to privatisation was the lack of clarity in the government's plans to liberalise the telecommunications sector, creating potential uncertainty in the valuation of TT by investors (Note 56).

Times were not exactly good for business investors (Note 57). The recent purchase of the Czech Český Telecom and critical reactions from financial sectors must also have weighed on the decision to give up a large market of 70 million inhabitants and with great growth potential but in need of heavy investment and management effort. In fact, the markets sent clear signals of their aversion to risks that would have been taken by Telefónica, which closed higher after announcing its resignation from Türk Telekom (Note 58).

\section{Entering New and Unexplored Markets in Non-Continental Europe: $\mathrm{O2}$}

The frenzy of mergers and acquisitions in the telecommunications industry prompted Telefónica, then the world's fifth largest operator by market value, to secure its presence in Europe in order to provide services in markets where the Group was not already present and to take advantage of growth opportunities or increase its service portfolio in other markets it already served (Note 59). In addition to BellSouth's acquisitions of assets in Latin America and the acquisition of Český Telecom, the purchase of the British mobile operator O2 brought European scale to Telefónica and was considered a landmark transaction in the process of consolidation of European telecommunications operators (Note 60). The literature pointed to the acquisition of $\mathrm{O} 2$ as a means of broadening Telefónica's reach across different markets and technologies (Note 61).

In fact, Telefónica's first steps in this area bear the label of a merger rather than an acquisition. The Spanish operator approached Dutch KPN NV to start negotiations on a wide range of issues, ranging from the possibility of full or partial integration of their businesses. Some reports went so far as to further specify the intentions, which were based on a joint venture with Telefónica holding $60 \%$ and the semi-public KPN $40 \%$ - more than $40 \%$ of its capital in the hands of the Dutch state. The bet meant the creation of a telecommunications giant worth 160 billion euros (Note 62).

It all came down to a tentative attempt in the context of other potential alliances with KPN. Telefónica and the Dutch operator suspended their merger talks by mutual agreement because they considered that the circumstances were not ideal. After six weeks of negotiations, the hard core of the operator, formed by BBVA and La Caixa, joined with two independent directors to bring the operation to a halt. Moreover, the operation did not have the approval of the Spanish government, which made acceptance of the merger between Telefónica and the operator 
KPN conditional on the Dutch government's irreversible and immediate relinquishment of its position as the company's main shareholder (Note 63).

The Spanish company then turned its sights on O2, the UK's largest incumbent telephone service company in 2001. Based in Slough, O2 had 15,000 employees and 24.6 million mobile customers in its home country, Ireland and Germany (Note 64).

It is necessary to pause to look at Telefónica's argument. The acquisition of $\mathrm{O} 2$ contributed to raising growth (fastest growing operator), achieving scale (increasingly important to better serve customers and expand efficiency by entering Europe's two largest markets with critical mass; integration of $\mathrm{O} 2$ to generate considerable synergies), rebalancing the portfolio (diversified exposure across businesses and regions) and gradual growth financially. These advantages ensured the industry's best combination of growth and cash returns through an offer that provided $\mathrm{O} 2$ shareholders with compelling value, price certainty and rapid execution (Note 65).

$\mathrm{O} 2$ meant a high quality asset to build Telefónica, a strong financial performance and expectations of superior cash flow growth. However, Telefónica highlighted differences in the different territorial constituents of O2. In the UK $\mathrm{O} 2$ was a high-growth operator in the largest European mobile market, while in Germany it meant obtaining critical mass and higher ARPU and strong upside potential and comparable in size to recent transactions; finally, $\mathrm{O} 2$ Ireland and Airwave offered an attractive operating profile (Note 66).

In November 2005, the Commission of the European Communities received a notification of a concentration whereby Telefónica S.A. acquired control of $\mathrm{O} 2 \mathrm{Plc}$ by means of an irrevocable takeover bid to acquire all the shares of $\mathrm{O} 2$, announced on 31.10.2005 and subsequently extended to January 2006. The Commission concluded that the transaction fell within the scope of the Merger Regulation and did not raise serious doubts as to its compatibility with the common market and the EEA Agreement. The concentration also had a Community dimension within the meaning of Article 1(2) of the Merger Regulation. Both parties provided telecommunications services at the retail level with significant differences. While $\mathrm{O} 2$ offered only mobile telecommunications services, Telefónica was active in fixed and mobile telephony. Both players offered international roaming services on their networks in different countries. In addition, they provided advanced pan-European mobile telecommunications services to multinationals (Note 67).

Telefónica financed the acquisition of $\mathrm{O} 2$ with a $£ 17.9$ billion (approximately EUR 26.4 billion) bank credit facility underwritten by Citigroup, Goldman Sachs and Royal Bank of Scotland. Their objective in structuring the transaction was to maintain the A rating or at worst to downgrade it by one notch. The financing came at the cost of significantly increasing the Company's indebtedness and lowering the Company's credit rating from the major rating agencies. In 2006, the loan was partially repaid through several long-term bond issues and the partial use of the Group's available cash. In addition, mid-December 2006, the terms and conditions of this loan were amended for the amount remaining at that date ( $£ 7$ billion), extending its duration. Obviously, the purpose of reducing indebtedness could disarm Telefónica to face competitive threats, to take advantage of attractive acquisition opportunities or to draw on cash resources. On the other hand, failure to meet the target would lead lenders to deny new loans and significantly reduce existing loans as they mature. In addition, such a failure could result in further downgrades of Telefónica's credit rating and, consequently, limit the Company's ability to raise long-term funds in the capital markets (Note 68).

\section{Conclusion}

In the new millennium, Telefónica continued the strategy of internationalisation that had begun substantially two decades earlier but now under the new era of the convergence of telecommunications and IT and in the transition to the predominance of the mobile telephony. The new phase was dominated by a selective strategy, which took the form of entry into open markets in large European countries and others with high growth potential in Eastern Europe and China. At the same time, markets that had been explored, including Turkey, were discarded.

It has been said that Telefónica's access to Europe was swift and decisive. To a certain extent, this is borne out by the figures, since in just two years, between 2004 and 2006, the continent went from contributing just over $4 \%$ of the company's revenues to $26 \%$. A closer reading points to a slow start because Telefónica had already been in different segments of the European market for a number of years. What happened was a major leap, not without previous failures.

\section{Annexe}

The Company is pleased to announce that the Company has entered into a SAA with Telefonica on 14 November 2005. Pursuant to the terms of the SAA, the Company and Telefonica shall build on the memorandum of 
understanding signed between them on 21 July 2005 to negotiate in good faith a strategic relationship for cooperation in a broad range of areas.

\section{Areas of strategic co-operation}

Subject to Telefonica becoming the beneficial owner of not less than the Threshold Percentage and compliance with applicable laws, the Company and Telefónica will, for a period of 6 months from the date of this Agreement, use reasonable efforts to negotiate in good faith a strategic relationship for cooperation in the following areas.

The possible areas of co-operation between the parties include: (a) international business area (including voice and IP Peering and IP MPLS); (b) the existing overseas business of the Company and its parent company subject to due diligence, agreeing on valuation and obtaining necessary approvals; (c) subject to due diligence, agreeing on valuation and obtaining necessary approvals, the provision of telecommunication businesses and services in the southern provinces in the PRC; (d) call center business (including worldwide call center services for Beijing Olympics 2008 and joint call center for outsourcing services); (e) management exchange involving senior managers from each of Telefonica and the Company for every six months during the term of the SAA; (f) cooperation and sharing in the areas of business development, network operations, customer acquisition and management, technology implementation, sales, marketing and branding in the PRC; (g) co-operation in the purchasing of technology, end-user equipment, infrastructure, distribution or usage rights and other components required to provide both fixed-line, broadband and wireless communications services; (h) technological assistance and knowledge transfer provided by Telefonica in the areas of value-added services, business solutions for smalland-medium-sized enterprises, IPTV solutions, mobile content services and other related areas; (i) the provision of mobile service, including, but not limited to, infrastructure, distribution or usage rights and other components required within the PRC when any mobile service licence has been issued in favour of the Company or its parent company; and (j) other forms of co-operation as may be mutually agreed by Telefonica and the Company (other than the areas set out in (a) to (i) above).

Information on the Company

The Company is incorporated in, and its shares are listed on the Stock Exchange and its ADSs are listed on the New York Stock Exchange. The Company is a leading fixed-line telecommunications operator in China and a leading international data communications operator in the Asia-Pacific region.

Information on Telefónica

Telefonica is an independent third party not connected with the Directors, chief executive or substantial shareholders of the Company or any of its subsidiaries or any of their respective associates. Telefonica is one of the largest telecommunications operators in the world with a strong track record of developing and operating across 18 countries in Europe, Latin America and Africa. Telefonica currently manages approximately 140 million customers in its operations worldwide.

\section{General}

The Company will negotiate in good faith with Telefonica as to the form and the terms of co-operation to be set out in separate definitive agreements and such agreements may or may not ultimately be entered into. No further indication can be given by the Company of the timing and details of the co-operation at this stage. Further announcements will be made by the Company when the terms of the separate definitive agreements are finalised and a director nominated by Telefonica is appointed to the Board.

The SAA may or may not become effective. In the meantime, investors are advised to exercise caution in dealing in the securities of the Company.

Definitions

"IP MPLS": Internet Protocol Multi Protocol Label Switching

"IP Peering": the act of one national Internet backbone provider accepting and passing traffic from another national provider.

SECURITIES AND EXCHANGE COMMISSION, WASHINGTON, D.C. 20549, Report of Foreign Private Issuer Pursuant to Rule 13a-16 or 15d-16 of the Securities Exchange Act of 1934 For the month of November, 2005.

\section{Acknowledgments}

This study is assigned to the Centre d'Estudis 'Antoni de Capmany' d'Economia i Història Econòmica, Department of Economic History, Institutions and Policy and World Economy, Faculty of Economics and Business 
(Universitat de Barcelona, Spain). I would like to thank those responsible for supporting my research as well as the editors and reviewers of this Journal.

\section{Primary Sources}

Securities and Exchange Commission, Nueva York

Telefónica

\section{The Public Library of US Diplomacy}

\section{Oral source}

Alejandro Díaz Garreta, Interviewed by the author, Madrid, 17 July 2013.

Luis López-van Dam, Interviewed by the author, 18 April and 13 May 2013.

Fernando Panizo, Interviewed by the author, 1 February 2017.

\section{Newspapers Library}

Business Wire

Cinco Días

El Mundo

El País

Expansión

Le Monde

L'Express

The Financial Times

TotalTelecom

\section{References}

Bel, G., \& Trillas, F. (2005). Privatization, corporate control and regulatory reform: the case of Telefonica. Telecommunications Policy, 29(1), pp. 25-51. https://doi.org/10.1016/j.telpol.2004.09.003

Bruce, R., \& Macmillan, R. (2002). Telecommunications in Crisis: Perspectives of the Financial Sector on Regulatory Impediments to Sustainable Investment. London: Debevoise \& Plimpton.

Calvo, A. (2019). Technological change, opening and internationalization of Spanish telecommunications. The transition to the third generation of mobile telephony. Harvard Deusto Business Research, 8(1), 3-30. https://doi.org/10.3926/hdbr.196

Calvo, Á. (2016). Historia de Telefónica: 1976-2000. Las telecomunicaciones en la España democrática. Barcelona: Ariel/Fundación Telefónica.

Calvo, Á. (2016a). Strategic Alliances in the European Industries of the Third Industrial Revolution. Journal of Evolutionary Studies in Business, 2(1), 235-265. https://doi.org/10.1344/jesb2016.2.j018

Casaldáliga, N. (2004). Campofrío. A growing company in a mature market. Madrid: EOI.

Chambers \& Partners. (2000). Chambers \& Partners global: The world's leading lawyers 2000-2001. London: Chambers \& Partners.

Chen, B. (2007). China Netcom Group International Strategy and Opportunities for Foreign Investors, Information Gatekeepers, May.

Chen, J., \& Shi, Huici. (2008). Mergers and Acquisitions in China: Impacts of WTO Accession. Chentelham: Edward Elgar.

Chorafas, D. N. (2006). Strategic Business Planning for Accountants: Methods, Tools and Case Studies. Oxford OX: Elsevier.

Cook, S. A. (2007). Ruling But Not Governing: The Military and Political Development in Egypt, Algeria, and Turkey. Baltimore: JHU Press.

Eichengreen, B. (2002). Crisis Prevention and Management: Any New Lessons from Argentina and Turkey?”, World Bank, Washington, pp. 1-35.

Fung et al. (2011). Foreign Direct Investment in Cross-Border Infrastructure Projects, ADBI Working Paper 274. 
Tokyo: Asian Development Bank Institute. https://doi.org/10.2139/ssrn.1800472

Gültekin, B. (2010). The Privatization of Turk Telekom: Case Study, Private Equity Workshop, Tenth Annual Private Equity Conference at the Federal Reserve Bank of Chicago International Private Equity: Southeast Europe Region, July.

Hulse, J. (2007). China's Expansion Into and U.S. Withdrawal from Argentina's Telecommunications and Space Industries and the Implications for U.S. National Security. Carlisle PA: Strategic Studies Institute. https://doi.org/10.21236/ADA471923

Immigration and Refugee Board of Canada (1999, March 1). Bulgaria: Corruption in the privatization of the Bulgarian Telecommunications Company or other government-owned enterprises; involvement of organized crime, and protection available to whistleblowers. BGR31249.E.

International Telecommunication Union (2002) 2002 World Telecommunication Development Report, 18-27 March. Istanbul, Turkey: World Telecommunication Development Conference.

Jelassi, T., \& Enders, A. (2005). Strategies for E-business: Creating Value Through Electronic and Mobile Commerce: Concepts and Cases. Harlow: Pearson Education.

KPMG Auditores. (2005). Informe de experto independiente en relación con el proyecto de fusión por absorción de Terra Networks, S.A. por Telefónica, S.A., on-line.

Moragas, V. (2011). La adquisición de O2 por Telefónica: valoración de una operación de referencia en el sector de las telecomunicaciones europeas, Barcelona: Escola Tècnica Superior d'Enginyeria de Telecomunicació.

Mourdoukoutas, P. (2015). Business Strategy in a Semiglobal Economy. London: Routledge. https://doi.org/10.4324/9781315705989

OECD (1997). Economic Surveys: Bulgaria 1997. Paris: OECD.

OECD (2000). Regulatory Reform in the Telecommunications Industry. Paris: OECD.

OECD (2002). OECD Reviews of Regulatory Reform: Turkey 2002 Crucial Support for Economic Recovery. Paris: OECD. https://doi.org/10.1787/9789264199255-8-en

Pederson, J. P. (2001). International Directory of Company Histories. St. James MO: St. James Press.

Proyecto de fusión de Telefónica, S.A. y Terra Networks, S.A. (2005). 23 February, Madrid.

Reuvid, J., \& Terte, M. (2005). Doing Business with the Czech Republic. London: GMB.

Ross, P. K. (2008). Management strategies in the Czech Telecommunications sector: A comparative study of Český Telecom and T-Mobile. International Journal of Human Resource Management, 19(12), 2216-2234. https://doi.org/10.1080/10301763.2009.10669392

Ross, P. K. (2006). Management strategies in transitional economies: Organisational restructuring and employment relations (ER) at Český Telecom. Employee Relations, 28(2), 184-200. https://doi.org/10.1108/01425450610639392

Securities and Exchange Commission, Form 20-F, 31December 2003, Commission file number 1-9531.

Securities and Exchange Commission, Form 20-F, 31 december 2005, Commission file number 1-9531.

Sokol, D. D. (2001, Fall). The European Mobile 3G UMTS Process: Lessons From the Spectrum Auctions and Beauty Contests. Virginia Journal of Law and Technology, 6, 1-31.

Telefónica (2001, 24 January). Joint Venture Agreement Telefónica S.A.-Portugal Telecom, SGPS, S. A. Corporate transactions.

Telefónica (2003, May 28). Terra Lycos minorities buy-out. Corporate transactions.

Telefónica, S. A. (2004, April). Document for the Registration of Bonds and Derivatives, Annex IV of Commission Regulation (EC) No 809/2004 of 29.

Telefónica (2005, October 31). "Delivering Balanced Growth and Cash Returns Through Enhanced Scale. Corporate transactions.

Telefónica. (2002, August). Suplemento al Folleto Informativo Continuado [Supplement to the Continuing Information Bulletin].

The Council of Economic Advisers (2000). The economic impact of third-generation wireless technology. Washington: The Council. 
Telecommunication Industry Association. (2001, March 30). Broadband Spectrum: The Engine for Innovation, Job Growth, and Advancement of Social Priorities, White Paper.

United States. Federal Communications Commission (2003). FCC Record: A Comprehensive Compilation of Decisions, Reports, Public Notices, and Other Documents of the ..., 18, 21. Washington: Federal Communications Commission.

United States of America. (2002, January 15). Before the Securities and Exchange Commission, Accounting and auditing enforcement, Release No. 1.494, Administrative Proceeding, File No. 3-10.678.

Valor, J. (2004). Competition in Spain's Telecommunications Sector. Barcelona: IESE Business.

Yalman, G. et al. (2018) The Political Economy of Financial Transformation in Turkey. Abingdon: Routledge. https://doi.org/10.4324/9781315669632

\section{Notes}

Note 1. International Telecommunication Union (2002), p. 3.

Note 2. International Telecommunication Union (2002), p. 18. In the USA, telecommunications accounted for 3 per cent of GDP in 1998, after growing at an annual rate of 7 per cent over the prior ten years: The Council of Economic Advisers (2000), p. 1.

Note 3. Fung et al. (2011), p. 5.

Note 4. OCDE (2000), pp. 38-43.

Note 5. Valor (2004), p. 12.

Note 6. Calvo (2016a), pp. 235-265.

Note 7. Significant event, 13 February 2003. Under the 2003 alliance, Terra Lycos would become Telefónica's exclusive supplier of the essential elements of the portal, use of the brand and aggregator of narrowband and broadband Internet services and content, whilst reserving for Terra the management and exploitation of advertising. In addition, Terra Lycos would preferentially channel through the Telefónica Group the acquisition, development and commercialisation of content and would preferentially distribute the online content of the Telefónica Group companies; it thus ensured the generation of a minimum annual value equivalent to 78.5 million euros: El Mundo, 13 February 2003. The asset restructuring and business integration with fixed telephony operations was the best option to create value for Telefónica and Terra Lycos shareholders: the purchase of minority stakes in Terra Lycos provided an attractive premium to Terra Lycos shareholders, higher than the premium that any other stand-alone company could potentially capture. The transaction enhanced Telefónica's shareholder value and advanced Telefónica's leadership in the Internet and broadband market in the countries where it maintained a presence: Telefónica (2003), p. 14. Telefónica strengthened its alliance with Bertelsmann by acquiring mediaWays, a Bertelsmann subsidiary offering Internet, data transmission and other business services. The aim of this acquisition, for a price of 282 billion pesetas, was to turn mediaWays into a springboard for Telefónica Data's development in Europe: Computerworld, 6 June 2000.

Note 8. With registered offices in Barcelona, it was incorporated for an indefinite period of time as Telefónica Comunicaciones Interactivas, S.A. on 4 December 1998.

Note 9. This was supported by the examples of the mergers of France Telecom and its Internet subsidiary Wanadoo and that of Deutsche Telekom and T-Online: Proyecto (2005), pp. 3-5.

Note 10. Increased customer and market share because of the increased responsiveness of the unified firm to competitors' integrated offerings; better position to create new services that optimise the use of Telefónica's network capabilities and fully integrate them into the end-customer service; strengthening the market offering by combining the positive attributes of the Telefónica and Terra brands and thereby reinforcing the leadership of the integrated firm; increasing the scale of operations and, therefore, the possibilities to address innovation projects and to better combine the commercial resources of the two companies; improving the leverage of existing customer bases, through (i) the ability to define and implement a global strategy by customer segment, beyond the current product-based approach; (ii) increasing penetration; (iii) building loyalty of existing customers by reducing churn rates through the bundling of services; (iv) increasing cross-selling of services; and (v) increasing revenues per customer as a result: Proyecto (2005), pp. 3-5.

Note 11. Telefónica, S.A., Documento de Registro de Obligaciones y Derivados [Registration of Bonds and Derivatives Document], Annexe IV of Commission Regulation (EC) No 809/2004 of 29 April 2004, pp. 17-20. 
Note 12. Telefónica (2001); SECURITIES AND EXCHANGE Commission, FORM 6-K, Commission File Number 1-13758, junio de 2010. Brauw Blackstone Westbroek advised on the creation of the Brasilcel holding company.

Note 13. Telefonica, "Reinforcing our undisputed leadership in the wireless sector in Brazil through the acquisition of Tele Centro Oeste Celular", January 16th, 2003.

Note 14. For details, see Telefónica Móviles, S.A., Financial statements for 2005, management report and auditor's report, pp. 16-17. On 30 June 2001 Telefónica merged Telefónica Móviles España, S.A. and Telefónica Móviles Intercontinental, S.A. on the basis of the Balance Sheets closed at 31 December 2000: BORME, 1,558, 13 August 2001, p. 19,846. At the proposal of the Executive Committee of Telefónica, S.A. (9 February 2005). (9 February 2005), the Boards of Directors of Telefónica and Terra Networks, S.A. approved a proposed merger by absorption of Terra Networks, S.A. by Telefónica, S.A. on the basis of two Telefónica shares for nine Terra Netwoks shares: Hecho relevante [Relevant fact], CNMV, 23/2/2005; Proyecto de fusión (2005). We are fully aware of the financial details of the transaction, which show the enormous technical complexity: KPMG Auditores (2005).

Note 15. United States. Federal Communications Commission 2003, p. 14.901. Before the opening to competition from 1998 onwards, BellSouth entered the Peruvian market in an open fight with Telefónica for the mobile segment, acquiring 59\% of the shares of Tele 2000 for 112 million dollars: Calvo (2016), p. 316. According to Davila and Elvira (2009, pp. 57-71), "For Telefónica, BellSouth was the ideal target company in terms of both the operational and geographic complementarities. With the acquisition of all the subsidiaries of BellSouth, Telefónica obtained in a single transaction a leadership position in Argentina, Chile, and Peru and gained entry into six new Latin American countries: Venezuela, Panama, Nicaragua, Uruguay, Colombia and Ecuador)”.

Note 16. SECURITIES AND EXCHANGE COMMISSION, FORM 8-K, October 13, 2004. Para la expansión latinoamericana de BellSouth, registrada en el estado de Georgia, remitimos a UNITED STATES OF AMERICA (2002).

Note 17. Telefónica Móviles, "Consolidation of leadership in Latin America”, March 8th, 2004, p. 17.

Note 18. The New York Times, 9 March 2004; Telefónica, Press release, Madrid, 7 January 2005. Other sources lowered customer figures in Latin America to around 41 million, behind Mexico's América Móvil's 44 million: The Wall Street Journal, 9 March 2004.

Note 19. For an obligatory reference to this matter, see Calvo 2019, pp. 3-30.

Note 20. The Wall Street Journal, 12 October 2000.

Note 21. By 2001, SPT Telecom changes its name to Český Telecom. The cap was raised to $78.1 \%$ if TelSource NV, one of the operator's shareholders, was involved: Reuvid and Terterov (2005), p. 139.

Note 22. Vivendi Universal (France), the media group, was reportedly in talks with the Czech government and approached financial circles about a possible joint bid for Cesky Telecom; however, it was excluded from the list of the most serious contenders: Telecompaper, 9 January 2002.

Note 23. Total Telecom, 8 August 2002. The figure of 82.6 billion kronor was reported in the press: New York Times, 7 April 2005. Český Telecom served almost 4 million fixed lines and controlled $51 \%$ of EuroTel, the leading mobile company with 3.4 million customers: Cinco Días, 8 August 2002. Texas-based SBC accentuated its plans to withdraw from Europe by announcing the sale of most of its stake in TDC, inherited when it took over rival Ameritech in 1999 with a purely financial rather than long-term intention. TDC was the dominant operator in Denmark with an $84 \%$ share of fixed-line subscribers and $33 \%$ of mobile customers: Financial Times, 10 June 2004. See also Ross 2008, pp. 2.216-2.234 and 2006, pp. 184-200. In June 2003, Cesky Telecom purchased from Atlantic West, a 50/50 joint venture between Verizon Communications and AT\&T Wireless, a 49 percent stake in Czech mobile operator Eurotel Praha: United States. Federal Communications Commission 2003 p. 14.884.

Note 24. Total Telecom, 19 June and 24 July 2002. JP Morgan, advisor to the operation for almost three years, suffered a setback with the suspension: Financial News, 3 December 2002.

Note 25. High price for Český Telecom pleases Czech Government, 2005 April 7, 05PRAGUE500_a. The France Telecom consortium, comprising Blackstone Group, CVC Capital Partners and Providence Equity Partners, was excluded from the privatisation of Cesky Telecom, apparently because it had linked its bid to the setting of a price identical to that proposed to minority shareholders: El Confidencial, 30 March 2005.

Note 26. MPR, 23 March 2005. 
Note 27. At that time, $48.9 \%$ of CT's shares, at CZK 412.5 (EUR 13) each, were listed on the Prague stock exchange, with a total value of over CZK 65bn (EUR $2.1 \mathrm{bn}$ ). PPF would have offered the highest price of all bidders, some CZK 71.3bn ( $€ 2.4$ bn): Business Weekly, 14 March 2005.

Note 28. Julio Linares, Primera Conferencia de Inversores, Rio de Janeiro, 2001.

Note 29. Telefónica, S.A., Documento de Registro de Obligaciones y Derivados, Annexe IV of Commission Regulation (EC) No 809/2004 of 29 April 2004, p. 24.

Note 30. Telefónica, S.A., Documento de Registro........ Regulation (EC) No 809/2004 of 29 April 2004. The European Commission did not see in the transaction a significant impediment to effective competition in the EEA or any substantial part of it: European Commission, IP/05/713, Brussels, 10 June 2005.

Note 31. The big press reported the figure of 82.6 billion kronor: The New York Times, 7 April 2005; a very close closing according to ThinkSpain, 7 April 2005, p. 1. In fact, the National Property Fund, a state agency, set the Telefónica's offer at SEK 502 (USD 21.50) per share, more than $25 \%$ above the closing share price, a real bombshell, according to an analyst at ING Financial Markets. Swisscom came second with (SEK 79.2 billion), followed by Belgacom (SEK 67.5 billion). Český Telecom, the former fixed-line monopoly, owned the country's largest mobile operator, Eurotel: The New York Times, 31 March 2005. Some media included France Télécom in the deal together with the excluded financial groups - The Blackstone Group, CVC Capital Partners and Providence Equity Partners - as the FNM considered that their offers included 'unacceptable' conditions and could 'jeopardise the approval of the transaction': Light Reading, 31 March 2005; according to more certain indications, France Télécom, as well as Vodafone, did not bid: Major European telecoms companies make preliminary offers for Český Telecom: 2005-02-10, The Public Library of US Diplomacy, 05PRAGUE197.

Note 32. ČESKÝ TELECOM, a. s., Half year report 2005, p. 2.

Note 33. ČESKÝ TELECOM, a. s., Half year report 2005, p. 2; El Confidencial, 14 October 2013; ABC, 13 April 2005.

Note 34. Commission of the European Communities, Case No COMP/M.4035 -TELEFÓNICA/O2, Regulation (EC) No 139/2004, merger procedure, Article 6(2) non-opposition, 10/1/2006.

Note 35. Telefónica, S.A. (2004); Telegeography, 21 September 2005; CFO Santiago Fernández Valbuena admitted a possible bond issue to finance his bid for the remaining $49 \%$ of the Czech phone company: $E l$ Confidencial, 16 June 2005.

Note 36. Some media outlets recalled the violent reaction of the conservative opposition to the high price paid for the entry into Peru, pointing out the relatively small difference with respect to rivals paid by Telefónica in the Czech Republic and the importance of the investment, the highest ever made by a Spanish company in Eastern Europe, including those of Campofrío in Russia or Ferrovial in Poland; the Council of Ministers formally approved the operation: $A B C, 10$ April 2005. Campofrío assumed a minimum investment risk of 3 million dollars Campomos, created at the end of 1989 in Moscow together with a local partner: Casaldáliga, 2004, p. 8; in 2000, Ferrovial acquired majority stake in Budimex, leading construction company in Poland: Pederson 2001, p. 219.

Note 37. Light Reading, 31 March 2005. In 2002, Telefónica bought Pegaso PCS, the second largest Mexican mobile operator, for $\$ 87$ million (plus the assumption of a debt of another $\$ 1,230$ million): Calvo (2016), p. 332.

Note 38. Český Reports: USD 244 million profit for 2004. Lehman Brothers considered "the potential acquisition of Český as positive for Telefónica", clarifying that "the purchase will have no impact on the share's cash returns", which, adding the dividend plus the share buyback plan, would reach a yield of close to $8 \%$. Lehman advised buying at a target price of 17.20 euros per share, giving it a potential of $30 \%$ compared to the last close. Ibersecurities reaffirmed its buy recommendation on Telefónica, giving it a $15 \%$ revaluation, although it advised entering at around 13 euros. Goldman Sachs downgraded its rating on the company from a "better than sector" recommendation to "in line with sector", noting that the aggressive pricing raised uncertainties about Telefónica's ambition in Central Europe and doubts about the company's future cash return. Standard \& Poor's also considered the price offered by Cesky "aggressive". The entities with which the loan was subscribed were ABN Amro, JP Morgan, Royal Bank of Scotland PLC, Banco Bilbao Vizcaya Argentaria, Banco Santander Central Hispano and La Caixa: El Confidencial, 5 April 2006, 4 April 2005 and 16 June 2005.

Note 39. CNMV, Relevant facts, 18.194, 21/4/2005. In mid-January, Goldman Sachs did not expect Telefónica to be seriously interested in Turk Telekom, even if it had submitted the necessary documentation; Ibersecurities ruled out that, after the purchase of Cesky, it would bid for Turk Telecom: El Confidencial, 4 April 2005.

Note 40. Gültekin (2010); Yalman et al. (2018). 
Note 41. Financial Times, 21 April de 2005; OECD (2002), p. 140; Arabian Business, 10 July 2001. President Bush urged Ecevit to proceed with the sale, seen as essential to put the economy on the right track: MEED, 45, 14-26, 2001, p. 19. In mid-1998, the World Bank participated in a round of informal meetings with high-level government and telecommunications representatives from five Eastern European countries, including the Czech Republic, to assess, in cooperation with the European Commission, the state of liberalisation of the telecommunications industry: Bruce et al. (1999), p. 1.

Note 42. We refer to several attempts to enter Eastern and Southern European countries, including Hungary, Russia and Greece: Calvo (2016).

Note 43. The government first declared BTC unavailable for privatisation but revised its decision and in late 1996 placed it on the privatisation 'emergency list' to sell 25 per cent of the company: OECD (1997), p. 138; Immigration and Refugee Board of Canada (1999). Viva Ventures Holding, a subsidiary of the British Advent International, acquired $65 \%$ of BTC for 230 million euros and committed to increase BTC's capital by $50 \mathrm{M}$. EUR, as well as to invest more than $50 \mathrm{M}$. EUR in the company. 50 million, as well as to invest more than EUR 700 million in the operator, the bulk in the first five years; the bidder planned to cut jobs. In the tender, the Turkish consortium Koc Holding Turk Telekom, the other bidder for BTC, offered EUR $185 \mathrm{M}$ but had foreseen softer staff reductions than Advent: Novinite, 30 January 2004.

Note 44. To better serve its multinational clientele, the company also developed a new website; in 1999, Chambers \& Partners advised Telefónica Intercontinental in its attempt to acquire shares in Bulgarian Telecommunication Company (BTC), Chambers \& Partners (2000); Novinite, 15 September 2009. We have been able to bring up this episode, barely documented, thanks to personal memory: Alejandro Díaz Garreta, Interviewed by the author, Madrid, 17 July 2013.

Note 45. Telefónica, Significant event, 21 December 2005. Several conditions weighed on the Bellsouth deal, for example in Chile where the Tribunal de Defensa de la Libre Competencia approved the merger between Telefónica Móviles and Bellsouth, which created the largest mobile operator in Chile. The agency set some conditions so that the merger would not affect free competition. Telefónica Móviles was seeking to merge its mobile telephony units spread across the continent with those of the American company, to better compete with Mexican giant América Móvil and Italian Telecom: SECURITIES AND EXCHANGE COMMISSION, FORM 6-K, Report of Foreign Private Issuer Pursuant to Rule 13a-16 or 15d-16 of the Securities Exchange Act of 1934 For the month of January, 2005, Commission File Number 001-09531; Emol, 4 January 2005; acquisition of Movicom, for an enterprise value of $\$ 988$ million. By combining the operations of Movicom and Unifon, Telefónica Móviles became the leading mobile operator in Argentina (with 5.5 million customers at the end of 2004) and was well positioned to capture a significant part of the high growth potential of the Argentinean mobile market: Business Wire, January $11,2005$.

Note 46. Simmons \& Simmons advised Telefónica on its strategic alliance with China Netcom: Simmons \& Simmons, 12 January 2006. The new Imperial Telephone Bureau opened the government-run telephone service in 1899; from 1949 to 1978 there was a fully protected market; from 1978 to 1994 the reform policy was initiated, from 1994 competition was introduced and in 2000 the monopoly was broken: Chen (2007). China Netcom sought out the partnership with Telefonica - the "taciturn lone ranger"- because it was interested in extending its geographical operations of fixed and mobile services. In September 2005, the company strengthened its presence with the purchase of another 2.01 per cent for USD 242 million and a seat on the board of directors: Financial Times, 26 October 2004; Hulse (2007), p. 16. International telecoms groups were vying to enter the Chinese market, whose mobile penetration rate was around 25 per cent, well below that of developed markets, yet they feared the "big trick of Chinese privatisations": Financial Times, October 14, 2005

China Netcom tried other operators, such as Singapore Telecom, Korea Telecom and Japan's NTT, but regulatory uncertainty in China's telecommunications sector deterred potential foreign investors from buying stakes in the operator. China Netcom pledged to present internationalisation as one of its three main strategies. The alliance and cooperation with Telefónica aimed in particular to strengthen Netcom's presence in southern China, where fixedline competitor China Telecom was predominant, and abroad. Telefónica would bring Netcom international management expertise and technology as well as capital. China Netcom was interested in the Latin American market, where Telefónica predominated as an operator: Financial Times, 25 July and 15 November 2005.

Note 47. The Beijing office was structured into units and functions so that the pre-sales manager, for example, had the task of dealing with customer requests and helping to provide solutions for customer needs; the multinational business unit and sales support prepared official responses to international tenders and business cases for customer proposals. The office was responsible, among other things, for commercial preparation, marketing campaigns and 
monitoring the company's financial situation. Mauricio Sartorius, Telefónica's chief representative in Beijing, said Telefónica's investment in Netcom was for the long term: Financial Times, 25 July 2005.

Note 48. With only a fifth of the mobile market, it could have more than 200 million customers by 2015. a booty worth taking a chance on: Financial Times, 7 July 2005; Telefónica, Annual Report, 2005, p. 16; Expansión, 30 June and September 2005; Cinco Días, 22 July 2005; El País, 22 November 2014; appointment of José María Alvarez-Pallete as non-executive director and CEO of the Strategic Planning Committee of China Netcom Group Corporation (Hong Kong) and Mauricio Sartorius, nominated by him, as an alternate director: SECURITIES AND EXCHANGE COMMISSION, Form 6-K, September 12, 2005. China Netcom was created by combining with Jitong Communications Company Ltd and the companies in the ten Northern provinces; between 2002 and 2004 it underwent a remarkable process of concentration: Chen and Shi (2008), p. 130. China Telecom, Netcom's former parent company, was the dominant operator in the more populous and wealthier south, which includes states such as Shanghai and Guandong, and entered the areas controlled by Netcom as the second operator. China Telecom was twice the size of its rival (some 147 million lines and 14 million ADSL compared to China Netcom's 67 million lines and 6 million ADSL): Expansión, 15 November 2005.

Note 49. Securities and Exchange Commission, FORM 6-K, November 14, 2005.

Note 50. Telefónica, S.A., Document on Registration of Bonds and Derivatives, Annex IV of the European Commission Regulation (EC) No 809/2004 of 29 April 2004, pp. 6-10. We have thoroughly exploited this exceptional document.

Note 51. Telefónica, S.A., Document on Registration of Bonds and Derivatives, Annex IV of the European Commission Regulation (EC) No 809/2004 of 29 April 2004, pp. 6-10.

Note 52. The credit rating agency Fitch took all of the company's debt classes off its "Rating Watch negative": Financial Times, 21 April 2005.

Note 53. Turk Telecom finally to be privatized?, 2004 December 1, 04ANKARA6673_a.

Note 54. Turk Telekom's privatization: optimism and gloom, 2005 May 17,05ANKARA2812_a. Macmillan Keck advised Koc Holding and Sabanci; BT Telconsult advised Saudi Oger Telecom. Army interests: Cook (2007), p. 21.

Note 55. Total Telecom, 24 January 2001. Strategic acquisitions are considered to be those involving smaller companies, often start-ups paid for by large corporations in cash or shares: Mourdoukoutas (2015), p. 112.

Note 56. Turk Telecom finally to be privatized?, 2004 December 1, 04ANKARA6673_a.

Note 57. Bruce and Macmillan (2002).

Note 58. ABC, 21 April 2005; Bolsamania, 21 April 2005; Telefónica, Annual Report, 2005, p. 16. International analysts strongly criticised Telefónica's purchase of Český for jeopardising the Spanish operator's plan to increase shareholder remuneration via dividends and share buybacks and making the acquisition of Móviles or its other subsidiary, TPI, unfeasible in the short and medium term: El Confidencial, 4 April 2005.

Note 59. The Wall Street Journal, 31 October 2005.

Note 60. Telefónica, S.A., Obligations and Derivatives Registration Document, Annexe IV of Commission Regulation (EC) No 809/2004 of 29 April 2004, p. 7; Moragas 2011. O2 was the result of the conversion of MMO2 PLC, the new name for BT Wireless; implausible as it sounds, O2 is the story of a jump from $£ 4$ billion to $£ 17.7$ billion in just four years: Young and Aitken (2007).

Note 61. Chorafas, 2006; Telefónica, Annual Report, 2005, p. 16.

Note 62. The scheduled launch of KPN Mobile on the Amsterdam Stock Exchange was postponed for a few weeks: El País, 30 April 2000; El Mundo, 30 April 2000.

Note 63. These insights nuance those of Bel and Trillas (2005), who speak simply of collusion between politicians and senior management. KPN blamed the break-up on Telefónica's internal division, an unsound basis for a merger, while acknowledging remarkable overlaps between the Dutch group and the Spanish company: corporate culture, common growth strategies and no interest by the parties in cost-cutting synergies. KPN was aiming for an equal shareholding; Villalonga would have held the top position of CEO and KPN two management positions, $\mathrm{CFO}$ and COO: El Mundo, 7 May 2000. As a $43 \%$ shareholder in KPN, the Dutch State would assert itself as a major shareholder in the new group, with 15 to $17 \%$ of the capital: Le Monde, 5 May 2000.

Note 64. TotalTelecom, 2 May 2000. 
Note 65. Telefónica, "Delivering Balanced Growth and Cash Returns through Enhanced Scale", Corporate transactions, October 31st, 2005, p. 23.

Note 66. Telefónica, "Delivering Balanced Growth and Cash Returns through Enhanced Scale", Corporate transactions, October 31st, 2005, pp. 12-16.

Note 67. Commission of the European Communities, Case No COMP/M.4035 -TELEFÓNICA/O2, Regulation (EC) No 139/2004, merger procedure, Article 6(2) non-opposition, 10/1/2006.

Note 68. Telefónica, S.A., Document of Registration of Bonds and Derivatives, Annex IV of Commission Regulation (EC) No 809/2004 of 29 April 2004, pp. 7-8; nuances in the figures - $£ 18.5$ bn (EUR 27.2 bn): Telefónica (2005), p. 21; £17.7 bn (\$31.4 bn or EUR 26 bn): The Wall Street Journal, 31 October 2005.

\section{Copyrights}

Copyright for this article is retained by the author(s), with first publication rights granted to the journal.

This is an open-access article distributed under the terms and conditions of the Creative Commons Attribution license (http://creativecommons.org/licenses/by/4.0/). 